OPEN ACCESS

Edited by:

Menghong $\mathrm{Hu}$,

Shanghai Ocean University, China

Reviewed by:

Amelia Portillo,

Autonomous University of Baja

California, Mexico

Carlos Alfonso Alvarez-González,

Universidad Juárez Autónoma

de Tabasco, Mexico

Wang Jiangyong,

South China Sea Fisheries Research

Institute (CAFS), China

Zahid Parvez Sukhan,

Chonnam National University, South Korea

*Correspondence:

Jackson A. Gross

jagross@ucdavis.edu

Specialty section: This article was submitted to

Aquatic Physiology,

a section of the journal

Frontiers in Marine Science

Received: 27 September 2021 Accepted: 03 February 2022

Published: 24 February 2022

Citation:

Boles SE, Neylan IP,

Rogers-Bennett $L$ and Gross JA

(2022) Evaluation of Gonad

Reproductive Condition Using

Non-invasive Ultrasonography in Red

Abalone (Haliotis rufescens).

Front. Mar. Sci. 9:784481.

doi: 10.3389/fmars.2022.784481

\section{Evaluation of Gonad Reproductive Condition Using Non-invasive Ultrasonography in Red Abalone (Haliotis rufescens)}

\author{
Sara E. Boles ${ }^{1,2,3}$, Isabelle P. Neylan ${ }^{1,2,4,5}$, Laura Rogers-Bennett ${ }^{1,2,6,7}$ and \\ Jackson A. Gross ${ }^{1,2,3 *}$
}

\begin{abstract}
${ }^{1}$ Bodega Marine Laboratory, University of California, Davis, Davis, CA, United States, ${ }^{2}$ Coastal and Marine Science Institute, University of California, Davis, Davis, CA, United States, ${ }^{3}$ Department of Animal Science, University of California, Davis, Davis, CA, United States, ${ }^{4}$ Center for Population Biology, University of California, Davis, Davis, CA, United States, ${ }^{5}$ Department of Evolution and Ecology, University of California, Davis, Davis, CA, United States, ${ }^{6}$ Karen C. Drayer, Wildlife Health Center, University of California, Davis, Davis, CA, United States, ${ }^{7}$ Bodega Marine Lab, California Department Fish and Wildlife, Bodega Bay, CA, United States
\end{abstract}

The reproductive status in abalone (Haliotis spp.) can be difficult to discern using traditional visual inspection methods and may therefore rely on lethal histological analyses for a definitive determination. With endangered species of abalone, lethal histological examinations are strictly prohibited due to their imperiled status. This research investigated the effectiveness of using non-invasive ultrasound technology as an alternate means of identifying the reproductive status of abalone rather than through invasive biopsies or lethal histological methods. Twelve abalone were randomly selected from cultured red abalone broodstock cohort $(n=200)$ produced at The Cultured Abalone Farm (Goleta, CA) to initially test these methods. Following initial gonad ultrasound determination, a subset of another cohort of 5 year-old $(n=62)$ red abalone produced at the UC Davis Bodega Marine Laboratory were monitored using ultrasonography to detect seasonal changes in gonad size for 7 weeks. Following the 7 -week assessment period, the full cohort of 5 -year old abalone $(n=122)$ were then spawned and gonads were also evaluated using ultrasound technology before and immediately after spawning. Ultrasound imaging technology accurately differentiated between digestive and reproductive tissues, allowing for the characterization of an ultrasound gonad index score for rapid assessment. Mean gonad thickness determined via ultrasound imaging was categorized on a scale of $1-5$, with an index of 1 being the lowest (gonad tissue thin or absent) and an index of 5 being the highest (gonad margin has increased and is compressing the digestive gland) for red abalone. Ultrasound imaging technology was successful in rendering a gonad index score that can be used to track gonad maturation over time in cultured or captive species. Tracking ultrasound gonad scores over time is a useful tool for improving abalone culture production, and increasing animal welfare by reducing handling stress associated with 
gonad assessments. Individual abalone that are empirically determined ready to be spawned can then be selected for broodstock. Non-invasive ultrasound technology has the potential for broad applications within abalone aquaculture to enhance both food and conservation aquaculture breeding programs.

Keywords: animal welfare, aquaculture, conservation, endangered species, reproductive biology, ultrasound

\section{INTRODUCTION}

Gonad condition provides powerful reproductive information for conservation and production aquaculture programs. Gonad assessments in aquatic organisms are traditionally invasive procedures and may induce significant handling stress and lead to mortality. Common procedures include palpation, compression, fine-needle aspirations, incisional biopsies, visual examination, and lethal histological examinations (Anderson et al., 1984; Rawson et al., 2003; Rogers-Bennett et al., 2004; Button and Rogers-Bennett, 2011). Improvements in ultrasound technology, such as image quality, ruggedness, and water resistance, allow for novel, non-invasive analyses in a variety of aquatic organisms (Shields et al., 1993; Daly et al., 2007; Novelo and Tiersch, 2012). Previously, ultrasound technology has been used to assess the reproductive condition and sex determination in finfish production aquaculture (Bonar et al., 1989; Blythe et al., 1994; Colombo et al., 2004; Næve et al., 2018) as well as in wild and imperiled species of fish (Evans et al., 2004; Swanson et al., 2008; Chiotti et al., 2016; Brizendine et al., 2018; Carim et al., 2021), but applications to aquatic invertebrate reproductive health is nonexistent.

Abalone (Haliotis spp.) are one of the most prized and valuable mass-produced mollusks, generating an estimated global market of $\$ 3$ billion USD (Cook, 2016). In addition to being a prized seafood item, California abalone bear cultural significance (Glassow, 1987; Vellanoweth et al., 2006; Field et al., 2008). Based on the presence of shell middens, it is believed that Indigenous peoples of California harvested abalone for their meat for thousands of years (Glassow, 1987; Vellanoweth et al., 2006), and have continued to use them for important ceremonial purposes (Field et al., 2008). Due to overfishing driven largely by commercial operations, populations of wild abalone have dramatically declined (Karpov et al., 2000; Hobday et al., 2001). Since then, abalone population declines have been further exacerbated due to a suite of factors including disease (Mayfield et al., 2011), increased poaching (Raemaekers et al., 2011), habitat degradation (Horiguchi et al., 2000), and environmental climate disasters (Takami et al., 2012; RogersBennett and Catton, 2019). Particularly along the west coast of the United States, abalone populations have further deteriorated by a "perfect storm" of environmental disasters leading to recent mass mortality events. These stressors include withering syndrome (Lafferty and Ben-Horin, 2013; Crosson et al., 2014), harmful algal blooms (De Wit et al., 2014), and starvation due to the catastrophic loss of kelp forests from warm ocean temperatures and sea urchin overpopulation (Rogers-Bennett and Catton, 2019). In 2018, the once robust recreational red abalone (H. rufescens) fishery in Northern California, worth upwards of \$44 million USD per year (Reid et al., 2016), was closed indefinitely after the collapse of the kelp forest (RogersBennett and Catton, 2019). Along with changes in climatic conditions, changes in habitat loss have negatively impacted the reproductive potential, or the relative capacity of an individual to reproduce under suboptimal conditions (Rogers-Bennett et al., 2010, 2021).

Abalone are long-lived, herbivorous, dioecious (separate sexes) broadcast spawners that reach reproductive age in the wild at 4-7 years of age, depending on the species and environmental conditions (Hahn, 1989). Male and female abalone release their gametes into the water for external fertilization, with embryos hatching within 18-36 hours after fertilization. Abalone larvae are free-swimming and lecithotrophic (non-feeding), and remain in the water column for 4-10 days (Hahn, 1989). Competent abalone larvae settle out of the water column and begin to metamorphose into crawling, feeding snails during which time they experience approximately $80-90 \%$ natural mortality (Hahn, 1989). Abalone species in both reproductive and developmental stages are sensitive to the same environmental perturbations such as ocean warming, ocean acidification, disease, and mass mortality events (Vilchis et al., 2005; Rogers-Bennett et al., 2010, 2021; Boles, 2020; Swezey et al., 2020).

For cultured mollusks such as abalone in which reproductive condition is challenging to assess, there exists an urgent need to determine gonad maturation for both food production and conservation aquaculture. Efforts to repopulate endangered abalone species have resulted in specialized captive breeding programs (Rogers-Bennett et al., 2016). However, reliable, noninvasive methods for evaluating reproductive competency to aid in abalone recovery are lacking. Current methods to evaluate abalone reproductive status include genetic sex determination (Klinbunga et al., 2009; Yang et al., 2019; Choi et al., 2021), invasive gonad tissue biopsies (Boolootian et al., 1962), seasonal visual inspection (Fallu, 1991), and lethal histological analysis (Ault, 1985; Rogers-Bennett et al., 2004). While visual inspections are useful, they are not always indicative that an individual will spawn. Furthermore, while examinations such as fine-needle aspiration and incisional biopsy do not pose a direct mortality risk (Button and Rogers-Bennett, 2011), they do pose a risk of immature gametes being released due to handling stress. Non-invasive ultrasound techniques to determine reproductive competency would significantly enhance both conservation and production aquaculture. While successful applications of ultrasound technology have been used to estimate reproductive state in finfish, these applications have remained unexplored in abalone. Assessments in abalone health using ultrasound technology have previously focused on shell lesions (Nollens et al., 2002), which affects the ability of the adductor muscle to 
attach to the shell causing increased mortality (Grindley et al., 1998); however, the application to assess the gametogenic cycle in abalone has not been explored.

The purpose of the present study is to evaluate the feasibility of using ultrasound technology as a non-invasive, low-stress methodology to assess the seasonal reproductive potential in sexually mature adult abalone. The overall goal is to develop the ultrasonographic technique for a rapid and more accurate assessment of fecundity in abalone. Ultrasound technology presents itself as an alternate and novel tool to assess the annual gonad reproductive state rather than lethal sampling or subjective visual inspection. Non-invasive ultrasonography methods would also increase animal welfare by reducing handling stress and potential lethality associated with hemolymph loss due to lack of clotting factors (Drew and Cantab, 1910; George and Ferguson, 1950; Armstrong et al., 1971) which can occur during tank removal. The objectives of this research project were to: (1) Assess the utility of ultrasonography as a tool to differentiate reproductive tissue from digestive tissue in sexually mature abalone, (2) Compare traditional histologically determined
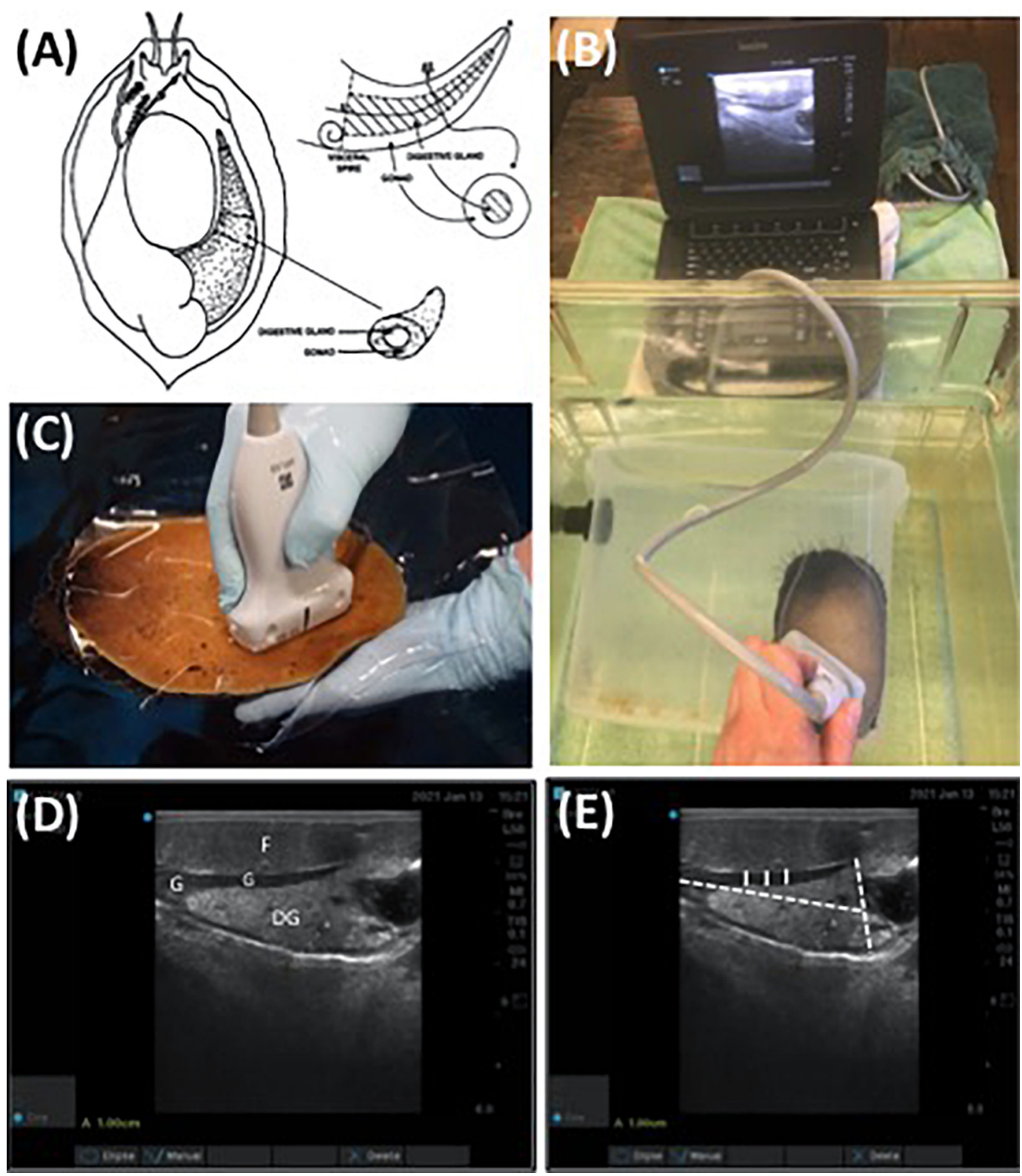

FIGURE 1 | (A) Diagram of abalone gonad and digestive gland (Rogers-Bennett et al., 2004), (B) non-invasive ultrasound assessment of red abalone (Haliotis rufescens) affixed to a submerged flow-through, polycarbonate aquaria, (C) ultrasound exam on red abalone immersed in seawater using transparency film, (D) ultrasound visualization of digestive gland (DG), foot (F), and gonadal tissue (G) of red abalone, and (E) replicate measurements of gonad thickness (solid white line) and maximum gonad cone height and length (dashed white line) were determined using non-invasive ultrasonography (D). Scale bar (A) = $1 \mathrm{~cm}$. 
gonad maturation scoring with a non-invasive assessment using ultrasound, and (3) Monitor gonad development throughout the annual gametogenic cycle and spawning. Ultrasound technology would benefit production aquaculture for farmed abalone such as California red abalone ( $H$. rufescens) and provide a noninvasive tool to assist in the conservation aquaculture of endangered abalone such as black ( $H$. cracherodii) and white (H. sorenseni) abalone.

\section{MATERIALS AND METHODS}

\section{Comparative Ultrasonography and Histological Evaluation}

\section{Animal Husbandry}

Red abalone ( $n=200$ sexually mature adult animals/ $\sim 100$ from each sex class) were sourced from The Cultured Abalone Farm (TCAF) (Goleta, CA) in February of 2020 and shipped overnight to the University of California, Davis' Bodega Marine Laboratory (Bodega Bay, CA). Red abalone were visually sexed by the distributor before shipping and were individually housed in $9 \mathrm{~L}$ flow-through polycarbonate aquaria (Aquaneering, San Diego, CA, United States). The abalone were fed a commercially sourced algal diet (AlgaMar, Ensenada, MEX) ad libitum for 8 months prior to gonad evaluations.

\section{Ultrasound Examination}

The digestive gland of an abalone is a cone shaped organ located on the right side of the mantle cavity between the foot and shell. The gonad envelopes around the outer section of the digestive gland (Figure 1A). The reproductive anatomies of 12 randomly selected red abalone $(n=6$ male and $n=6$ female) obtained from the cohort of 200 abalone sourced from TCAF were imaged using SonoSite Edge II Ultrasound System with a HFL50 15-6 MHz probe (Mechanical Index = 0.7; Thermal Index $=0.1$; Read Depth $=6$; exam type $=$ breast) (FUJIFILM SonoSite, Bothell WA). A 9 L polycarbonate tank with a single animal affixed to the walls was completely

TABLE 1 | Classification of the qualitative visual ultrasound gonad index scoring system in red abalone (Haliotis rufescens).

\begin{tabular}{|c|c|}
\hline $\begin{array}{l}\text { Ultrasound } \\
\text { gonad score }\end{array}$ & Visual subjective description \\
\hline 1 & $\begin{array}{l}\text { Black gonad margin absent around digestive gland } \\
\text { cone (Figure 3B). }\end{array}$ \\
\hline 2 & $\begin{array}{l}\text { Black gonad margin present; however, margin does not } \\
\text { fully envelope digestive gland cone (Figure } \mathbf{3 C} \text { ). }\end{array}$ \\
\hline 3 & $\begin{array}{l}\text { Increased thickness of black gonad margin is observed } \\
\text { and gonad margin is fully enveloped around the } \\
\text { digestive gland (Figure 3D). }\end{array}$ \\
\hline 4 & $\begin{array}{l}\text { Black gonad margin has increased thickness and is still } \\
\text { fully enveloped around gonad cone; no constriction of } \\
\text { digestive gland is observable due to thickening of } \\
\text { gonad (Figure 3E). }\end{array}$ \\
\hline 5 & $\begin{array}{l}\text { Thickness of black gonad margin has increased and is } \\
\text { compressing the digestive gland (Figure } \mathbf{3 F} \text { ). }\end{array}$ \\
\hline
\end{tabular}

immersed in seawater in a $75.7 \mathrm{~L}$ fiberglass tank. Ultrasound assessments of the abalone were conducted ventrally, placing the transducer against the polycarbonate rearing tank and imaging directly through the foot. Gonad cone length, maximum gonad cone height, and gonad thickness from the ultrasound images were used as empirically derived data. Mean gonad thickness was analyzed with Image J software (v1.50i) using up to three ultrasound images per abalone. Each image consisted of three measurements to account for abalone movement and each image was individually standardized to account for differences in image resolution. Gonad thickness measurements were recorded at three locations across the thickest, medial

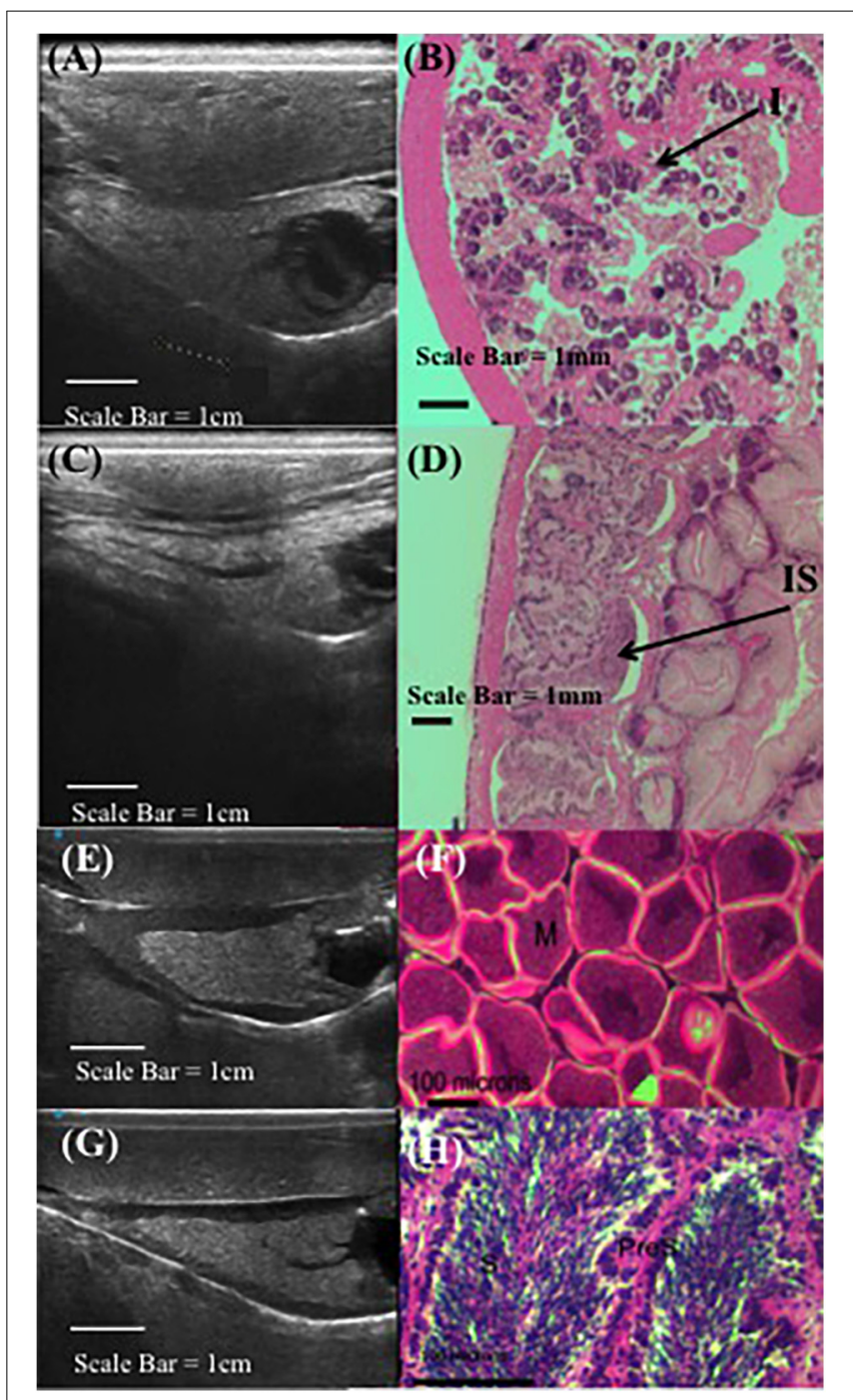

FIGURE 2 | Comparative red abalone (Haliotis rufescens) histology and ultrasonography. Paired ultrasound (A) and histology (B) images from a non-reproductive female, where (I) indicates immature oocytes. Paired ultrasound (C) and histology (D) images from a non-reproductive male, where (IS) indicates immature spermatocytes. Unpaired ultrasound (E) and histology in gravid female (F), where (M) indicates mature eggs. Unpaired ultrasound (G) and histology (H) in male abalone, where (S) indicates sperm and (PreS) indicates pre-sperm. Note, (F) and (H) from Rogers-Bennett et al. (2010). 
portion of the gonad (Figure 1D). For each image, a mean gonad thickness from the three measurements was determined and the mean from the three images was utilized as a final measurement.

\section{Histological Examinations}

Following the completion of the ultrasound, unripe abalone $(n=12)$ were anesthetized using magnesium chloride, weighed, measured, and sacrificed for histology. For histological examinations, abalone with mature gonads were not available for lethal histological analysis as they were part of a long-term, transgenerational reproduction study and archived histological images from known ripe male and female abalone were used in lieu for illustrative purposes (Rogers-Bennett et al., 2010). The digestive gland and gonad were measured, excised, and weighed. Histological evaluation of gonad tissue was accomplished by excising the gonad section and placing it into a cassette. The abalone gonad tissue in the cassette was fixed using a formalinbased invertebrate solution (Davidsons) then transferred to 95\% ethanol. Once fixed, abalone gonad tissue was stained with hematoxylin and eosin (H\&E) embedded in wax, cut, and 5 $\mu \mathrm{m}$ thick sections were mounted on slides and covered by glass coverslips (Histology Consultation Services, Everson WA) (for methods description see Rogers-Bennett et al., 2004). Histology slide images of gonad tissues were taken using a microscope (Olympus BH2-RFCA, Japan), lens (Olympus 6H01072, Japan), and camera (OMAX A3514OU, China).

\section{Ultrasonography Gonadal Score Development, Continuous Monitoring, and Post-spawning Assessment Quantitative Ultrasound Assessments}

In this study, a subset of sexually mature 5-year-old red abalone $(n=62)$ from a cohort cultured at the Bodega Marine Lab
( $n=122)$ were utilized to quantitatively track seasonal changes in gonadal maturation using ultrasonography. Assessments were conducted twice, first in winter (January) when the reproductive potential is low, and again in (April) when abalone gonad maturation may be greater. Gonad cone length, maximum gonad cone height, and gonad thickness were measured using Image J as described previously.

\section{Qualitative Ultrasound Assessments}

To qualitatively track weekly changes in gonadal maturation, an ultrasonography gonad index scoring system was established to correlate with digital quantitative ultrasound assessments. To assess individual gonad maturation, repeated qualitative scoring (from 1 to 5 with a score of 1 being the lowest) (Table 1) assessments were conducted once per week on a subset of red abalone $(n=14)$ during the 7-week period between January and April 2021.

\section{Ultrasound Assessment Before and After Spawning}

To verify abalone gonad maturation and to assess the ability of ultrasonography to detect changes in abalone gonad size before and after spawning, the full cohort of red abalone assessed during the 7 -week period $(n=122)$ were induced to spawn following the established method of using a solution of $3 \% \mathrm{H}_{2} \mathrm{O}_{2}$ and 1 M TRIS in UV filtered seawater (Moss et al., 1995; Boles, 2020; Swezey et al., 2020). Red abalone broodstock were removed from polycarbonate aquaria during pre-dawn hours and placed into a clear 2.37 L container (Evercoat \#100789, Cincinnati, $\mathrm{OH}$ ) containing spawning solution. The spawning container was lined with transparency copier film (3M \# PP2950, Austin, $\mathrm{TX)}$ to reduce handling stress. Ultrasounds were performed before and after spawning was induced on female $(n=6)$ and male $(n=5)$ red abalone by removing the abalone from their container while still affixed to the transparency film and then immersing them in a 20-gallon fiberglass tank containing
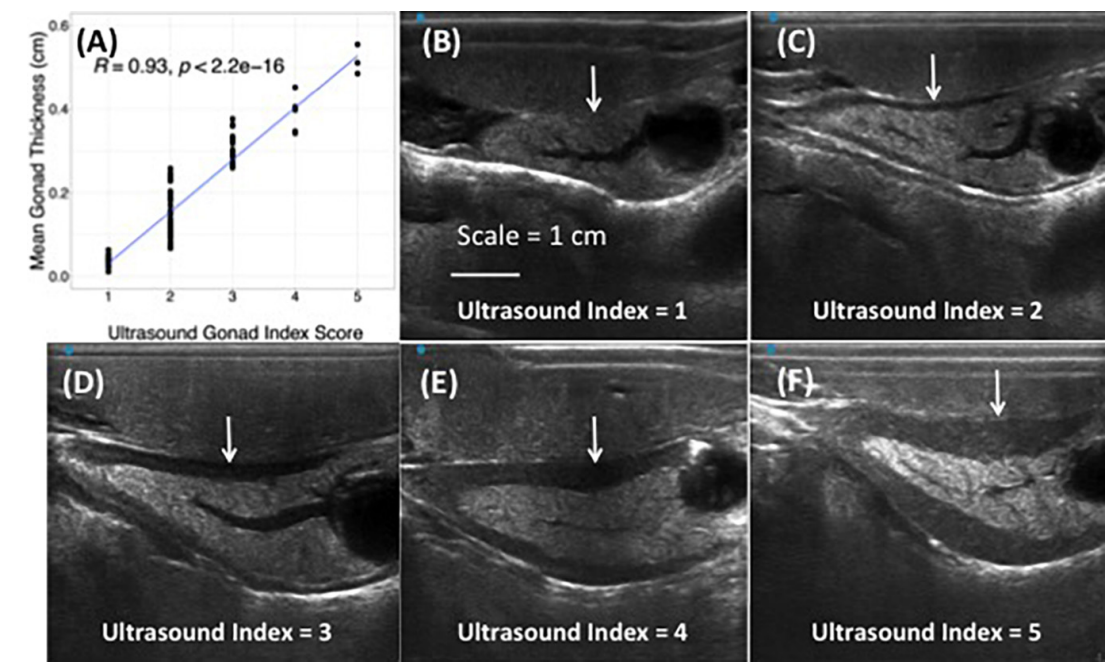

FIGURE 3 | Correlation between quantitative mean gonadal thickness and qualitative ultrasound gonad index scores in cultured red abalone (Haliotis rufescens) (A). Ultrasound visual index classification: $(\mathbf{B})$ index $=1,(\mathbf{C})$ index $=2,(\mathbf{D})$ index $=3,(\mathbf{E})$ index $=4$, (F) index $=5$. Scale $=1 \mathrm{~cm}$. White arrows indicate progressive thickening of abalone gonad. 

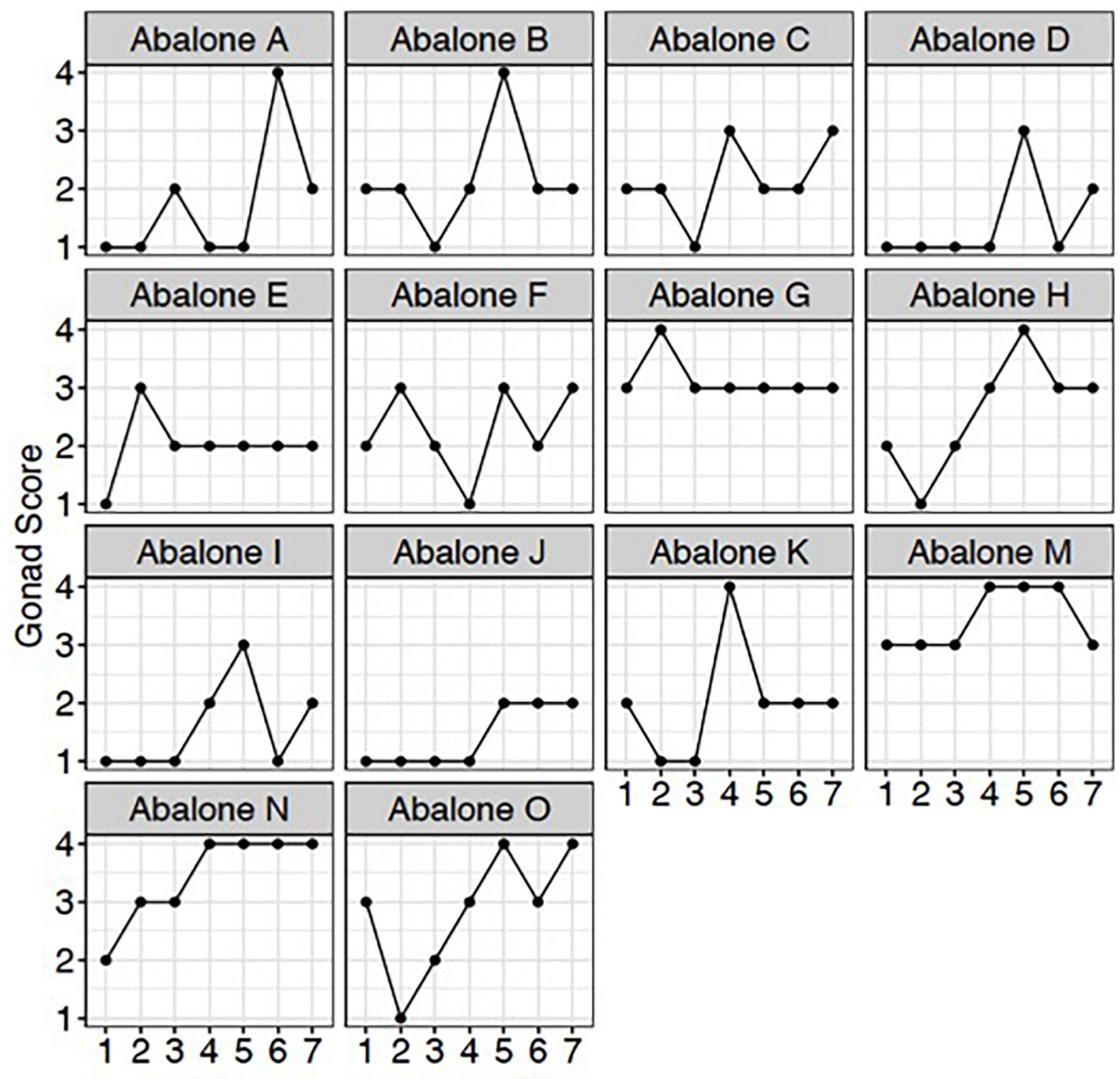

\section{Ultrasound Assessment Week}

FIGURE 4 | Red abalone (Haliotis rufescens) weekly ultrasound gonad scores. Each panel represents an individual abalone's gonad development across the 7-week assessment period.

spawning solution in UV filtered seawater. Ultrasounds were performed directly through the transparency film to prevent the abalone from adhering to the ultrasound probe and to minimize handling stress associated with removing animals off the container walls.

\section{Data Analysis}

Data analysis and visualization was conducted in $\mathrm{R}$ Studio (version 1.1.463) (Wickam, 2016). Pearson's correlation analysis was performed to assess the significance of the relationship between gonad thickness and the ultrasound gonad score. Means and standard deviations were calculated for abalone gonad thickness, total weight, and maximum shell length.

\section{RESULTS}

Ultrasound technology was capable of differentiating between the cone-shaped digestive organ (light gray) and the gonad (black band) enveloped around the cone (Figure 1). The thickness of the black band representing gonad tissue wrapped around the conical-shaped digestive gland reflected females having mature 


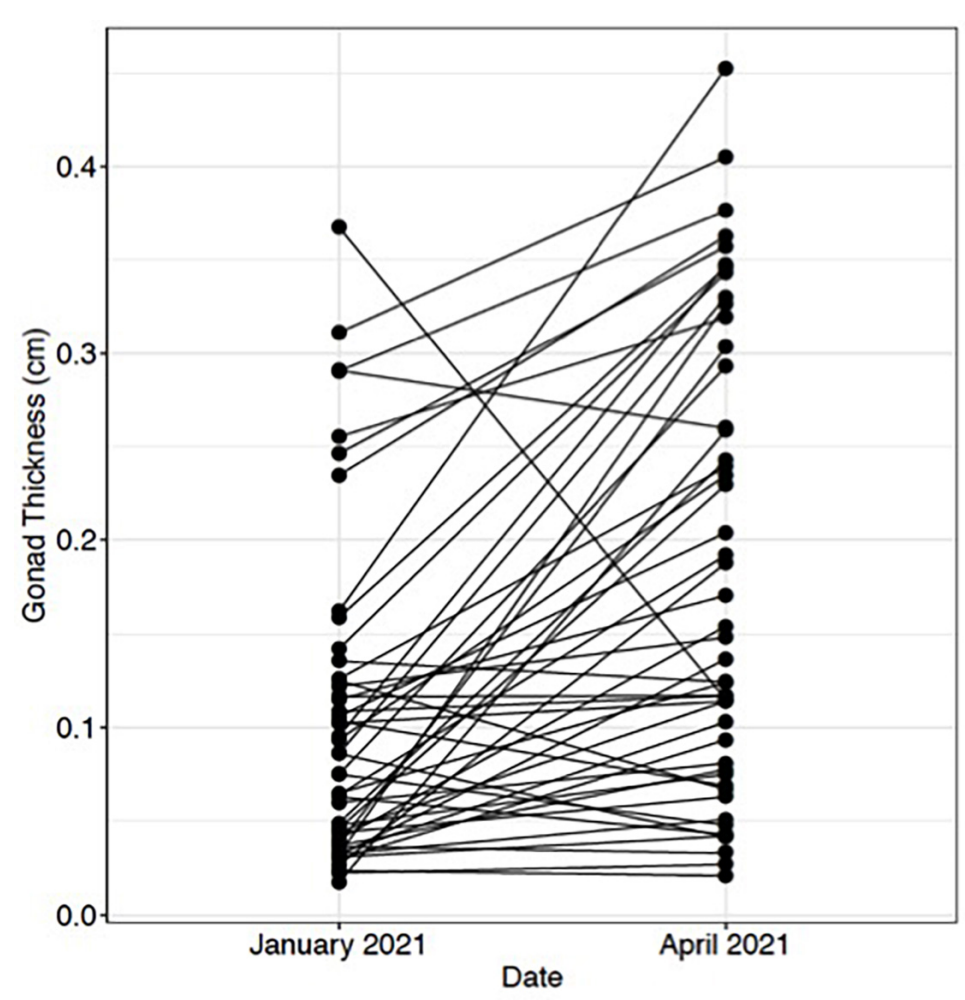

FIGURE 5 | Change in red abalone (Haliotis rufescens) gonadal thickness from January 2021 to April 2021. Each point represents an individual abalone and black lines indicate change in gonadal thickness.

eggs present and males being full of sperm (Figure 2). When the gonad tissue was thin or absent this reflected female abalone having immature eggs and male abalone being full of spermatids with few mature sperm present. Note, since histology required lethal sampling, the histology images used in this manuscript for ripe male and female (Figures 2E-H) were not taken from the same individuals from which the ultrasound images were recorded and are solely for illustrative purposes (Rogers-Bennett et al., 2010); all other histology and ultrasound images are derived from the same individual (Figures 2A-D). To confirm abalone were reproductive, animals were induced to spawn and resulting gametes were fertilized and larvae successfully hatched. While a relationship between gonad cone length and maximum gonad cone height was detected; these metrics were not a reliable indicator of gamete maturation associated with the annual gametogenic cycle.

Ultrasound imaging also captures changes in the thickness of the gonad layer, which was found to be highly correlative to the reproductive status of the animal $(R=0.93 ; P<2.2 \mathrm{e}$ 16) (Figure 3). Mean length and weight for 5-year-old red abalone used in this study was $101.06 \mathrm{~mm}( \pm 13.94)$ and $196.83 \mathrm{~g}$ $( \pm 78.48)$, respectively. An ultrasound gonad index or a visual assessment score was modified from Rogers-Bennett et al. (2004) and developed to assign to gonad thickness (Table 1 and Figures 3A-E). Mean gonad thickness was used as a categorical delineation for the visual ultrasound gonad index assessment score in red abalone as 1-5. Mean gonad thickness for each score
(1-5) was: Score $1=0.036 \mathrm{~cm}( \pm 0.011)$, Score $2=0.144 \mathrm{~cm}$ $( \pm 0.054)$, Score $3=0.31 \mathrm{~cm}( \pm 0.035)$, Score $4=0.378 \mathrm{~cm}$ $( \pm 0.041)$, Score $5=0.517 \mathrm{~cm}( \pm 0.035)$. The ultrasound gonad index score provided an accurate qualitative measure to monitor the reproductive state of gonad tissue in red abalone throughout the spawning cycle (Figure 4). Changes in gonad thickness were detected in abalone between the January 2021 and the April 2021 ultrasound assessments (Figure 5).

\section{SPAWNING}

Ultrasound examination detected changes in gonad tissue thickness in both female and male red abalone before and after spawning (Figure 6). Female red abalone had an average prespawn gonadal thickness of $0.25 \mathrm{~cm}( \pm 0.06)$ and an average post-spawn gonadal thickness of $0.19 \mathrm{~cm}( \pm 0.05)$, representing a $21.1 \%$ change in female gonad thickness before and after spawning (Figures 6A,C,D). Male red abalone had an average gonad thickness of $0.31 \mathrm{~cm}(\mathrm{SD} \pm 0.09)$ before spawning and an average post-spawn gonadal thickness of $0.26 \mathrm{~cm}( \pm 0.11)$, representing a $17.8 \%$ change in gonad thickness before and after spawning (Figures 6B,E,F). Abalone ultrasound index score is an excellent indicator that an abalone will spawn. Ultrasound imaging found that 30,100 , and $75.4 \%$ of abalone, which scored an index of 5, 4, and 3, respectively, spawned when chemically induced. 

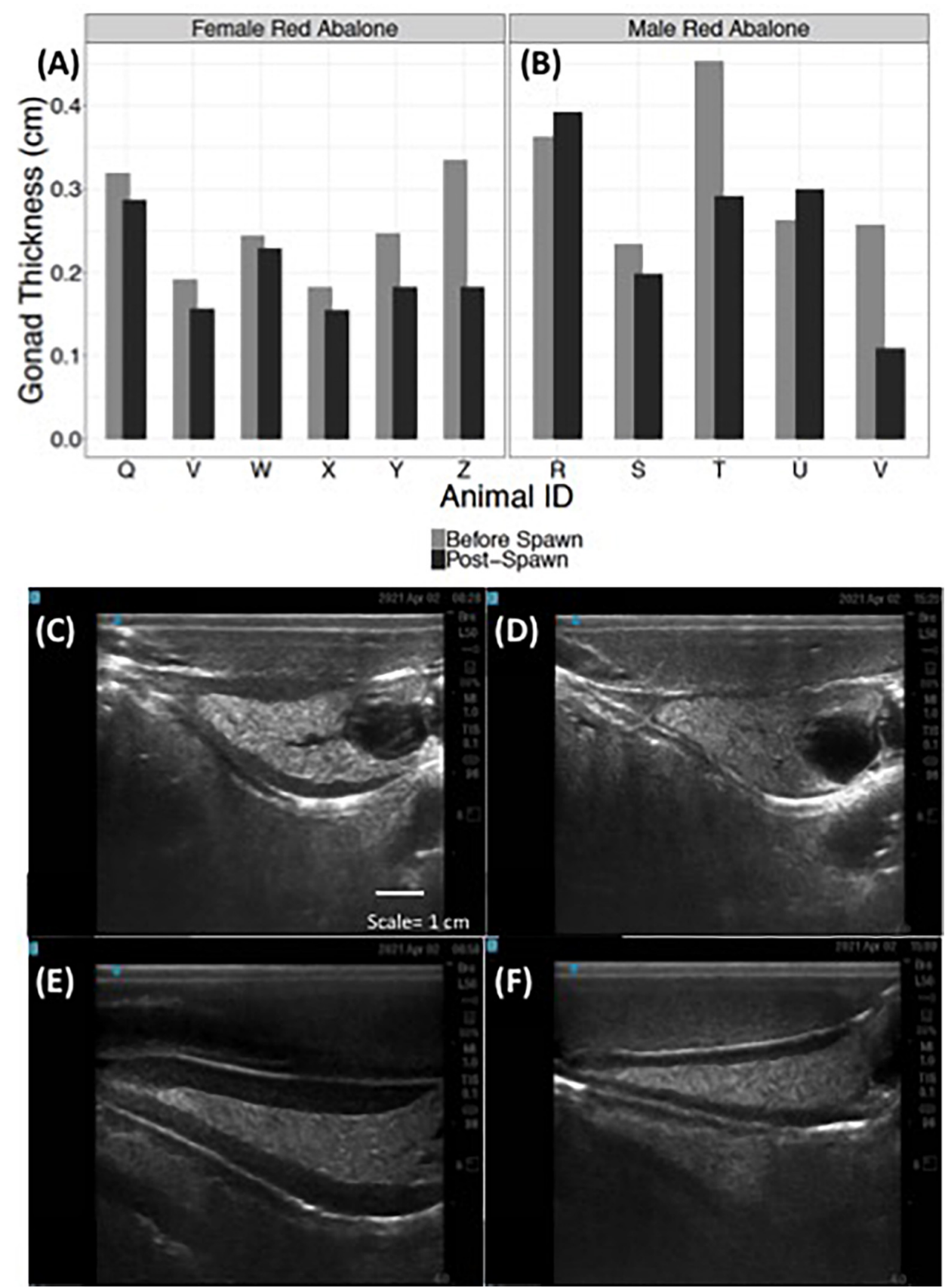

FIGURE 6 | Ultrasonography detects changes in red abalone (Haliotis rufescens) gonad thickness before and post-spawning. Quantitative changes in gonad thickness in female $(n=6)(\mathbf{A})$ and male $(n=5) \mathbf{( B )}$ abalone before (light gray bars) and after spawning (black bars). Ultrasound images of a female abalone before (C) and after spawning (D) and of a male abalone before (E) and after spawning (F).

\section{DISCUSSION}

This research utilized cultured red abalone (Haliotis rufescens) to demonstrate the effectiveness of non-invasive ultrasound technology to distinguish between adult reproductive gonadal and digestive tissues. A descriptive ultrasonography gonad index score was developed that correlated with gonad thickness using ultrasound inspection (Table 1 and Figure 3).
Notable results from this exploratory use of ultrasound technology in abalone reproductive biology include: (1) the ability to quantify changes in gonad thickness to detect seasonal variation as well as identify changes before and after spawning and (2) the development of the ultrasound gonad index score to qualitatively track abalone reproductive state throughout the annual gametogenic cycle without removing animals from aquaria. 
Ultrasound technology is an effective and quantitative non-invasive method for successfully determining the reproductive state of gonads in cultured red abalone. With the cost of ultrasound units becoming more affordable, imaging technology will allow hatchery managers the convenient and clear visualization of gonad development. Ultrasound technology was found to be highly sensitive and demonstrated the ability to detect relatively small changes in gonad volume. The ability to detect changes in reproductive development will assist aquaculture managers in scheduling broodstock spawning events (Shields et al., 1993; Martin-Robichaud and Rommens, 2001); this is important when spawning endangered species of abalone. Standard methods used to induce spawning of abalone impose minor chemical stress on the animals (Moss et al., 1995), therefore information gained from ultrasonography pertaining to whether an animal has already spawned or not gravid can reduce unnecessary exposure.

Measuring abalone gonad condition in individual animals was accomplished quickly when utilizing ultrasound. Ultrasonography is regularly employed to rapidly assess the gonad maturation state in many aquatic species such as the Lake Sturgeon (Acipenser fulvescens) in order to reduce handling stress and invasive biopsies (Chiotti et al., 2016) or to identify pre and post-spawn adult steelhead trout for use in fisheries management (Evans et al., 2004). Ultrasound use increases animal welfare in abalone by reducing the need for physical manipulation and the potential injury of animals to assess spawning readiness or when handling stress or injury associated with removal from the tank. Over handling can induce early spawning and reduce overall fertilization and reproductive output. Increasing the animal welfare around handling and spawning activities is also especially important when working with endangered and wild species of abalone. In October 2021, the European Union (EU) Treaty on the Functioning of the European Union (TFEU) adopted the Farm to Fork resolution that encourages the development and implementation of enhanced animal welfare methods for marine invertebrates (European Commission, 2021). While there are no parallel resolutions in the United States regarding marine invertebrate welfare, the speed, ease, and reduced risks of ultrasonography assessments would be beneficial to animal welfare on both domestic and international commercial abalone farms or conservation hatcheries.

The utility of incorporating ultrasound assessments with husbandry practices reduces the guesswork of gonad maturation by physical manipulation alone and provides economic benefits in the abalone aquaculture industry. The ability to monitor animals throughout the annual gametogenic cycle to assess the reproductive potential of broodstock and direct spawning activities on gonad mature animals reduces the likelihood of a poor spawning event and failed larval recruitment. In most instances, ultrasound technology reduces the labor associated with handling broodstock and efficiently records a gonad index while measuring the gonad across the polycarbonate-rearing tank. In the few instances when an abalone was affixed in a corner of the tank, it was assessed another day. The ability to obtain visual gonad scores through a submerged tank inside of a larger tank was quick and time-efficient. This technique would optimize gathering gross morphometric data and measuring spawning readiness in many animals. While the transmissibility of the tanks, and in some cases the "bucket", was acceptable, the transmissibility of the ultrasound and the subsequent image was greatly improved by using the transparency film described in the methods section. If the goal is to conduct health assessments or gather accurate and reliable data from images, imaging the abalone across transparency film is preferred.

Ultrasonography was shown to be a valuable strategy in determining the reproductive state of abalone and is important for broodstock selection by determining which individual abalone should be spawned. Future studies in ultrasound technology for abalone should explore its potential applications in sex determination, parasitism, disease prognosis, cardiac function, and stress physiology. These sublethal and nonlethal methods are critical to elevate the animal welfare of abalone especially when assessing the health of endangered and threatened species of abalone, and enhancing commercial aquaculture and conservation breeding programs. Ultrasound technology and the techniques outlined here provide empirical, non-invasive, rapid methods for assessing abalone reproductive status as compared to current visual gonad scoring systems. The implications of this research could include utilizing ultrasound technology described here for other commercially and ecologically important shellfish.

\section{DATA AVAILABILITY STATEMENT}

The original contributions presented in the study are included in the article. Further inquiries can be directed to the corresponding author/s.

\section{AUTHOR CONTRIBUTIONS}

SB and JG designed the research. SB, IN, and JG performed the research. SB and IN refined ultrasound use. SB, IN, LR-B, and JG analyzed the data and wrote the manuscript. All authors contributed to the article and approved the submitted version.

\section{FUNDING}

This research was funded by the United States Navy, Commander Pacific Fleet N62473-19-2-0023.

\section{ACKNOWLEDGMENTS}

We thank A. D. Schroeder for comments and editing suggestions during manuscript preparation. We thank D. S. Swezey for assistance in spawning red abalone broodstock. We thank K. Menard, J. Newman, and P. Smith for assistance with facilities support and R. DeSantiago, A. Juarez, and R. Farzad for their assistance in preparing ultrasound for use and animal husbandry. 
We want to extend a special thank to A. Deutsch for assistance in routine animal care and $\mathrm{C}$. Vines for use of microscope equipment. We thank B. C. Marshman for assistance with

\section{REFERENCES}

Anderson, S. A., Chang, E. S., and Clark, W. H. Jr (1984). Timing of postvitellogenic ovarian changes in the ridgeback prawn Sicyonia ingentis (Penaeidae) determined by biopsy. Aquaculture 42, 257-271. doi: 10.1016/ 0044-8486(84)90106-6

Armstrong, D. A., Armstrong, J. L., Krassner, S. M., and Pauley, G. B. (1971). Experimental wound repair in the black abalone, Haliotis cracherodii. J. Invert. Pathol. 17, 216-227. doi: 10.1016/0022-2011(71)90094-2

Ault, J. S. (1985). Some quantitative aspects of reproduction and growth of the red abalone, Haliotis rufescens Swainson. J. World Maricult. Soc. 16, 398-425. doi: 10.1111/j.1749-7345.1985.tb00221.x

Blythe, B., Helfich, L. A., Beal, W. E., Bosworth, B., and Libey, G. S. (1994). Determination of sex and maturational status of striped bass (Morone saxatilis) using ultrasonic imaging. Aquaculture 125, 175-184. doi: 10.1016/00448486(94)90294- 1

Boles, S. E. (2020). Ocean acidification and settlement diet differentially affect survival between two populations of red abalone (Haliotis rufescens), Department of Environmental Toxicology. California: University of California, Davis.

Bonar, S. A., Thomas, G. L., Pauley, G. B., and Martin, R. W. (1989). Management briefs: use of ultrasonic images for rapid nonlethal determination of sex and maturity of Pacific herring. North Am. J. Fish. Manag. 9, 364-366. doi: 10.1577/ 1548-8675(1989)009<0364:MBUOUI>2.3.CO;2

Boolootian, R. A., Farmanfarmaian, A., and Giese, A. C. (1962). On the reproductive cycle and breeding habits of two western species of Haliotis. Biol. Bull. 122, 183-193. doi: 10.2307/1539587

Brizendine, M. E., Ward, D. L., and Bonar, S. A. (2018). Effectiveness of ultrasonic imaging for evaluating presence and maturity of eggs in fishes in remote field locations. North Am. J. Fish. Manag. 38, 1017-1026. doi: 10.1002/nafm.1 0200

Button, C. A., and Rogers-Bennett, L. (2011). Vital rates of pink abalone Haliotus corrugata estimated from mark-recapture data to inform recovery. Mar. Prog. Series 431, 151-161. doi: 10.3354/meps09094

Carim, J. E., Relyea, S., Barfoot, C., Eby, L. A., Kronenberger, J. A., Whiteley, A. R., et al. (2021). Ultrasound imaging identifies life history variation in resident Cutthroat Trout. PLoS One 16:e0246365. doi: 10.1371/journal.pone.0246365

Chiotti, J. A., Base, J. C., Hondrop, D. W., and Briggs, A. S. (2016). Assigning sex and reproductive status to adult Lake Sturgeon using ultrasonography and common morphological measurements. North Am. J. Fish. Manag. 36, 21-29. doi: 10.1080/02755947.2015.1103823

Choi, M., Oh, Y. D., Kim, Y. R., Lim, H. K., and Kim, J. (2021). Use of a gene encoding zona pellicida 4 as a female-specific marker for early stage sexual differentiation and size dimorphism in the Pacific abalone. Hal. Dis. Hannai. 225:106687. doi: 10.1016/j.anireprosci.2021.106687

Colombo, R. E., Wills, P. S., and Garvey, J. E. (2004). Use of ultrasound imaging to determine sex of shovelnose sturgeon. North Am. J. Fish. Manag. 24, 322-326. doi: 10.1577/M03-016

European Commission (2021). Communication from the Commission to the European Parliament, the Council, the European Economic and Social Committee and the Committee of the Regions: A Farm to Fork Strategy: European Parliament resolution of 20 October 2021 on a farm to fork strategy for a fair, healthy and environmentally-friendly food system (2020/2260(INI)). P9_TA_(2021)0435. Brussels: European Commission

Cook, P. A. (2016). Recent trends in worldwide abalone production. J. Shellf. Res. 35, 581-583. doi: 10.2983/035.035.0302

Crosson, L. A., Wright, N., VanBlaricom, G. R., Kiryu, I., Moore, J. D., and Friedman, C. S. (2014). Abalone withering syndrome: distribution, impacts, current diagnostic methods and new findings. Dis. Aquat. Org. 108, 261-270. doi: $10.3354 /$ dao02713

Daly, J., Gunn, I., Kirby, N., and Galloway, D. (2007). Ultrasound examination and behavior scoring of captive broadnose sevengill sharks, Notorynchus cepedianus (Peron, 1807). Zoo Biol. 26, 383-395. doi: 10.1002/zoo.20155 histological sample preparations. We thank J. Bredvik and S. Graham of Navy Marine Ecology Consortium for their expertise and assistance in all aspects of this study.

De Wit, P., Rogers-Bennett, L., Kudela, R. M., and Palumbi, S. R. (2014). Forensic genomics as a novel tool for identifying the causes of mass mortality events. Nat. Commun. 5:3652. doi: 10.1038/ncomms4652

Drew, G. H., and Cantab, B. A. (1910). Some points in the physiology of lamellibranch blood-corpuscles. Q. J. Microscop. Sci. Archiv. 54, 605-621. doi: $10.1242 /$ jcs.s2-54.216.605

Evans, A. F., Fitzpatrick, M. S., and Siddens, L. K. (2004). Use of ultrasound imaging and steroid concentrations to identify maturation status in adult steelhead. North Am. J. Fish. Manag. 24:3. doi: 10.1577/M03-112.1

Fallu, R. (1991). Abalone farming. Oxford: Fishing News Books, 41.

Field, L. W., Seinder, C., Lang, J., Cambra, R., Silva, F., Hailstone, V., et al. (2008). Abalone Tales: Collaborative explorations of sovereignty and identity in Native California. doi: $10.2307 /$ j.ctv125jkbz

George, W. C., and Ferguson, J. H. (1950). The blood of molluscs. J. Morphol. 86, 315-327. doi: 10.1002/jmor.1050860205

Glassow, M. A. (1987). "The occurrence of red abalone shells in Northern Channel Islands archeological middens: Implications for climatic reconstruction," in $3^{\text {rd }}$ California Islands Symposium, (Santa Barbara Musuem).

Grindley, R., Keogh, J., Friedman, C., Cook, P., Davis, G. E., Haaker, P., et al. (1998). Shell lesions in New Zealand Haliotis spp. (Mollusca, Gastrapoda). J. Shellfish Res. 17, 805-811.

Hahn, K. O. (1989). Handbook of Culture of Abalone and Other Marine Gastropods. Boca Raton, FL: CRC Press.

Hobday, A. J., Tegner, M. J., and Haaker, P. L. (2001). Over-exploitation of a broadcast spawning marine invertebrate: Decline of the white abalone. Rev. Fish Biol. Fish. 10, 493-514. doi: 10.1023/A:1012274101311

Horiguchi, T., Takiguchi, N., Cho, H. S., Kojima, M., Kaya, M., Shiraishi, H., et al. (2000). Ovo-testis and disturbed reproductive cycle in the giant abalone, Haliotis madaka: possible linkage with organotin contamination in a site of population decline. Mar. Env. Res. 50, 223-229. doi: 10.1016/S0141-1136(00) 00071-4

Karpov, K. A., Haaker, P. L., Tanigichi, I. K., and Rogers-Bennett, L. (2000). Serial depletion and the collapse of the California abalone (Haliotis spp.) fishery. Can. J. Fish. Aquat. Sci. 130, 11-24.

Klinbunga, S., Amparyup, P., Khamnantong, B., Hirono, I., Aoki, T., and Jarayabhand, P. (2009). Isolation and characterization of testis-specific DMRT1 in the tropical abalone (Haliotis asinine). Biochem. Genet. 47, 66-79. doi: 10.1007/s10528-008-9207-1

Lafferty, K. D., and Ben-Horin, T. (2013). Abalone farm discharges the withering syndrome pathogen into the wild. Front. Microb. 4:373. doi: 10.3389/fmicb. 2013.00373

Martin-Robichaud, D. J., and Rommens, M. (2001). Assessment of sex and evaluation of ovarian maturation of fish using ultrasonography. Aquac. Res. 32, 113-120. doi: 10.1046/j.1365-2109.2001.00538.x

Mayfield, S., McGarvey, R., Gorfine, H. K., Burch, P., and Sharma, S. (2011). Survey estimates of fishable biomass following a mass mortality even in an Australian molluscan fishery. J. Fish Dis. 344, 287-302. doi: 10.1111/j.1365-2761.2011. 01241.x

Moss, G. A., Illingworth, J., and Tong, L. J. (1995). Comparing two simple methods to induce spawning in the New Zealand abalone (paua), Haliotis iris. New Zeal. J. Mar. Freshw. Res. 29, 329-333. doi: 10.1080/00288330.1995.9516667

Næve, I., Mommens, M., Arukwe, A., and Kjørsvik, E. (2018). Ultrasound as a noninvasive tool for monitoring reproductive physiology in female Atlantic salmon (Salmo salar). Physiolog. Rep. 6:e13640. doi: 10.14814/phy2.13640

Nollens, H. H., Schofield, J. C., Keogh, J. A., and Probert, P. K. (2002). Evaluation of radiography ultrasonography and endoscopy for detection of shell lesions in live abalone Haliotis iris (Mollusca: Gastropoda). Dis. Aquat. Org. 50, 145-152. doi: 10.3354/dao050145

Novelo, N. D., and Tiersch, T. R. (2012). A review of the use of ultrasonography in fish reproduction. North Am. J. Aquac. 74, 169-181. doi: 10.1080/15222055. 2012.672370 
Raemaekers, S., Hauck, M., Bürgener, M., Mackenzie, A., Maharaj, G., Plagányi, ÉE., et al. (2011). Review of the causes of the rise of the illegal South African abalone fishery and consequent closure of the rights-based fishery. Ocean Coast. Manag. 54, 433-445. doi: 10.1016/j.ocecoaman.2011.02.001

Rawson, P. D., Slaughter, C., and Yund, P. O. (2003). Patterns of gamete incompatibility between blue mussels Mytilus edulis and M. trossulus. Mar. Biol. 143, 317-325. doi: 10.1007/s00227-003-1084-x

Reid, J., Rogers-Bennett, L., Vasquez, F., Pace, M., Catton, C. A., Kashiwada, J. V., et al. (2016). The economic value of the recreational red abalone fishery in northern California. Calif. Fish Game 102, 119-130.

Rogers-Bennett, L., Dondanville, R. F., and Kashiwada, J. (2004). Size specific fecundity in red abalone (Haliotis rufescens): evidence for reproductive senescence? J. Shell. Res. 23, 553-560.

Rogers-Bennett, L., Dondanville, R. F., Moore, J. D., and Vilchis, L. I. (2010). Response of Red Abalone Reproduction to Warm Water, Starvation, and Disease Stressors: implications of Ocean Warming. J. Shell. Res. 29, 599-611. doi: 10.2983/035.029.0308

Rogers-Bennett, L., Aquilino, K. M., Catton, C. A., Kawana, S. K., Walker, B. J., Marshmann, B. C., et al. (2016). Implementing a restoration program for the endangered white abalone (Haliotis sorenseni) in California. J. Shell. Res. 35, 611-618. doi: 10.2983/035.035.0306

Rogers-Bennett, L., and Catton, C. A. (2019). Marine heatwave and multiple stressors tip bull kelp forests to sea urchin barrens. Sci. Rep. 9:1. doi: 10.1038/ s41598-019-51114-y

Rogers-Bennett, L., Klamt, R., and Catton, C. A. (2021). Survivors of climate driven abalone mass mortality exhibit declines in health and reproduction following kelp forest collapse. Front. Mar. Sci. 8:725134. doi: 10.3389/fmars.2021.725134

Shields, R. J., Davenport, J., Young, C., and Smith, P. L. (1993). Oocyte maturation and ovulation in the Atlantic halibut, Hippoglossus hippoglossus (L.), examined using ultrasonography. Aquac. Fish. Manag. 24, 181-186. doi: 10.1111/j.13652109.1993.tb00539.x

Swanson, P., Campbell, B., Shearer, K., Dickey, J., Beckman, B., Larsen, D., et al. (2008). Application of reproductive technologies to captive breeding programs for conservation of imperiled stocks of Pacific salmon. Cybium 32, 279-282.

Swezey, D. S., Boles, S. E., Aquilino, K. M., Stott, H. K., Bush, D., Whitehead, A., et al. (2020). Evolved differences in energy metabolism and growth dictate the impacts of ocean acidification on abalone aquaculture. Proc. Natl. Acad. Sci. 117, 26513-26519. doi: 10.1073/pnas.2006910117

Takami, H., Won, N.-I., and Kawamura, T. (2012). Impacts of the 2011 megaearthquake and tsunami on abalone Haliotis discus hannai and sea urchin Strongylocentrotus nudus populations at Oshika Peninsula, Miyagi, Japan. Fish. Oceanogr. 22, 113-120. doi: 10.1111/fog.12008

Vellanoweth, R. L., Rick, T. C., Erlandson, J. M., and Reynolds, G. (2006). A 6,000 year old red abalone midden from Otter Point, San Miguel Island, California. North Am. Archaeol. 27, 69-90. doi: 10.2190/M525-1140-2546-0566

Vilchis, L. I., Tegner, M. J., Moore, J. D., Friedman, C. S., Riser, K. L., Robbins, T. T., et al. (2005). Ocean warming effects on growth, reproduction, and survivorship of Southern California Abalone. Ecolog. Appl. 15, 468-480. doi: 10.1890/035326

Wickam, H. (2016). RStudio Team. Boston, MA: RStudio Team.

Yang, Z., Xu, F., Zhang, Z., Li, J., Jia, Y., Li, H., et al. (2019). Genetic determination of sex and shell color in the Pacific abalone Haliotis discus hannai by an integrated linkage map. Anim. Genet. 50, 733-739. doi: 10.1111/age. 12860

Conflict of Interest: The authors declare that the research was conducted in the absence of any commercial or financial relationships that could be construed as a potential conflict of interest.

Publisher's Note: All claims expressed in this article are solely those of the authors and do not necessarily represent those of their affiliated organizations, or those of the publisher, the editors and the reviewers. Any product that may be evaluated in this article, or claim that may be made by its manufacturer, is not guaranteed or endorsed by the publisher.

Copyright (c) 2022 Boles, Neylan, Rogers-Bennett and Gross. This is an open-access article distributed under the terms of the Creative Commons Attribution License (CC BY). The use, distribution or reproduction in other forums is permitted, provided the original author(s) and the copyright owner(s) are credited and that the original publication in this journal is cited, in accordance with accepted academic practice. No use, distribution or reproduction is permitted which does not comply with these terms. 